\title{
BMJ Open Effects of universally offered parenting interventions for parents with infants: a systematic review
}

\author{
Maiken Pontoppidan, ${ }^{1}$ Sihu K Klest, ${ }^{2}$ Joshua Patras, ${ }^{2}$ Signe Boe Rayce ${ }^{3}$
}

To cite: Pontoppidan M, Klest SK, Patras J, et al. Effects of universally offered parenting interventions for parents with infants: a systematic review. BMJ Open 2016;6:e011706. doi:10.1136/bmjopen-2016011706

- Prepublication history and additional material is available. To view please visit the journal (http://dx.doi.org/ 10.1136/bmjopen-2016011706).

Received 27 February 2016 Revised 15 July 2016 Accepted 25 August 2016

CrossMark

${ }^{1}$ SFI-The Danish National Centre for Social Research and University of Copenhagen, Copenhagen, Denmark

${ }^{2}$ Health Sciences Faculty, University of Tromsø, Arctic University of Norway, Tromsø, Norway ${ }^{3}$ SFI-The Danish National Centre for Social Research, Copenhagen, Denmark

Correspondence to Maiken Pontoppidan; mpo@sfi.dk

\section{ABSTRACT}

Objectives: From a developmental perspective, infancy is a critical stage of life. Early childhood interventions aim to support caretakers, but the effects of universal interventions for parents with infants are unknown. The objective is to determine the effects of universal parenting interventions offered to parents with infants $0-12$ months on measures of child development and parent-child relationship.

Design: A systematic review using the Preferred Reporting Items for Systematic Reviews and MetaAnalysis. We extracted publications from 10 databases in June 2013, January 2015 and June 2016 and supplemented with grey and hand search. Risk of bias was assessed, and effect sizes were calculated.

Participants: Inclusion criteria are: (1) randomised controlled trials of structured, psychosocial interventions offered to a universal population of parents with infants $0-12$ months old in western OECD countries, (2) interventions that include a minimum of 3 sessions with at least half of the sessions delivered postnatally and (3) programme outcomes reported for child development or parent-child relationship.

Results: 14 papers representing 7 studies are included. There were no statistically significant effects of the intervention for the majority of the primary outcomes across the studies.

Conclusions: The findings of this review are mixed. No clear conclusions can be drawn regarding the effects of universally offered parenting interventions on child development and parent-child relationship for this age group.

\section{INTRODUCTION}

The importance of early experiences in children's long-term development is well established. The first year of life is a period of rapid development critical to infants' health, emotional well-being and developmental trajectories. ${ }^{12}$ The first signs of mental health problems are often exhibited during infancy; however, the symptoms may be overlooked by parents and healthcare providers because they can be less intrusive when a child is young. ${ }^{3-8}$ Early onset of emotional or behavioural

\section{Strengths and limitations of this study}

- Comprehensive search strategy and screening procedure.

- Includes child development and parent-child relationship outcomes.

- Meta-analyses could not be performed due to outcome heterogeneity.

problems increases the risk of numerous adverse outcomes that persist into adolescence and adulthood, such as delinquency, violence, substance abuse, mental health problems, teen pregnancies, school dropout and long-term unemployment. ${ }^{1}$ 4 4 9-14

Parents are crucial for the healthy development of infants as they are primarily responsible for the environment in which the child develops. Pregnancy and birth, particularly of a first child, is a period of major lifestyle changes that can be stressful for mothers and fathers. ${ }^{15-17}$ The highest rates of child neglect and violent abuse occur when children are under 5 years of age, ${ }^{18}{ }^{19}$ with the most serious cases of injury and death caused by parental violence against children occurring when infants are under 1 year of age. ${ }^{20}$

Early childhood interventions aim to make the first year of parenthood easier by supporting caretakers. These interventions typically focus on improving adjustment and function in the family by teaching parents to use specific skills or strategies that foster healthy child development. ${ }^{21}$ Parenting interventions can be delivered within an indicated, selective or universal framework. ${ }^{22} 23$ Indicated interventions are offered to families with known risk factors or professional evaluations that suggest the parents or the child may be experiencing problems. ${ }^{22} 23$ Selective interventions are typically offered to families who come from environments that are known to have risk factors, such as neighbourhoods with low socioeconomic status or high crime rates. ${ }^{22} 23$ Finally, universal 
interventions are offered to all families in a population regardless of existing risk factors or identified problems, therefore, they have the widest reach. ${ }^{22} 23$

Individual studies and reviews suggest that high-quality parenting interventions delivered to families within the indicated and selective populations can mitigate problems at a relatively low cost. ${ }^{2} 1011{ }^{24-30}$ The effectiveness of individual universal interventions has been evaluated, but no reviews currently exist of universal interventions aimed at supporting parents with infants aged $0-12$ months. It is important to determine the effectiveness of universal interventions because they offer several potential advantages over indicated and selective approaches: (1) universal interventions are offered to all families, and they can reach those in need in a non-stigmatising setting, which may increase the number of families with problems who accept support; (2) these interventions may be an effective method of identifying families who require extra support or further treatment before problems reach elevated levels. Parents who are neglectful or emotionally or physically abusive to their children do not necessarily meet any of the criteria that would indicate they may be at risk of harming their children and they may, therefore, never come to the attention of professionals who could offer support; (3) finally, universal interventions may be an effective method of reducing the overall levels of child maltreatment and developmental problems within the general population because they have the potential to reach all families. Targeted interventions do not generally reach enough families to see population-level effects (eg, reduction in emergency room visits due to child abuse or population level reduction in child mental health problems). ${ }^{22}$ 31-33

The aim of this review is to systematically review universally offered interventions for parents with infants aged 0 12 months. Randomised controlled trials (RCTs) of interventions reporting outcomes for child development or parent-child relationship are included in the review.

\section{METHOD}

\section{Search strategy}

This review was conducted according to the Preferred Reporting Items for Systematic Reviews and Meta-Analyses (PRISMA). We did not register a protocol. The database searches were performed in June 2013 and updated in January 2015 and June 2016. We searched 10 international bibliographic databases: Campbell Library, Cochrane Library, CRD (Centre for Reviews and Dissemination), ERIC, PsycINFO, PubMed, Science Citation Index Expanded, Social Care Online, Social Science Citation Index and SocIndex. Operational definitions were determined for each database separately. The main search was made up of conjunctions of the following terms: infant*, neonat*, parent*, mother*, father*, child*, relation*, attach*, behavi*, psychotherap*, therap*, intervention*, train*, interaction, parenting, learning and education. The searches included Medical Subject Headings (MeSH), Boolean operators and filters. The year of publication was not restricted. In addition, we searched for grey literature; hand searched four journals and snowballed for relevant references.

\section{Eligibility criteria and study selection}

All publications were screened based on abstract and title. Publications which could not be excluded were screened based on the full-text version. Inclusion and exclusion criteria are presented in table 1 .

Each publication was screened by two research assistants under close supervision by MP and SBR. Uncertainties regarding inclusion were discussed with MP and SBR. Screening was performed in Eppi-Reviewer 4.

\section{Data extraction and risk of bias assessment}

We developed a data extraction tool for the descriptive coding and extracted information on (1) study design, (2) sample characteristics, (3) setting, (4) intervention details, (5) outcome measures and (6) child age postintervention and at follow-up. The extracted information was checked by SBR. Primary outcomes were child socioemotional development and parent-child relationship. Secondary outcomes were other child development markers, such as cognitive development. When reported, total scores and subscale scores were extracted. Outcomes were extracted and reported for mothers and fathers when provided, and were combined to a single measure of child development outcome if feasible.

Numeric coding of outcome data was conducted independently by MP and SBR. Disagreements were resolved by consulting a third reviewer. Risk of bias was assessed separately for each relevant outcome for all studies based on a risk of bias model developed by Professor Barnaby Reeves and the Cochrane Nonrandomized Studies Method Group (Reeves, Deeks, Higgins, and Wells, unpublished data, 2011). This extended model is organised and follows the same steps as the existing risk of bias model presented in the Cochrane Handbook, Chapter $8 .{ }^{34}$ The assessment was conducted by SBR. Any doubts were discussed with another member of the review team.

\section{Analyses}

Meta-analyses were planned; however, it was not possible to report results due, to heterogeneity in the outcome measures and timing of follow-up assessments of program outcomes. We calculated effect sizes for all relevant outcomes with sufficient data provided in the article. Effect sizes were reported using standardised mean differences (Cohen's d) with 95\% CIs for continuous outcomes. Cohen's d and its SE are calculated as:

$$
\begin{gathered}
\mathrm{d}=\left(\mathrm{X}_{1}-\mathrm{X}_{2}\right) / \mathrm{s}_{\mathrm{p}} \\
\mathrm{SE}_{\mathrm{d}}=\left[\left(\mathrm{N} / \mathrm{n}_{1} \mathrm{n}_{2}\right)+\left(\mathrm{d}^{2} / 2 \mathrm{~N}\right)\right]^{1 / 2}
\end{gathered}
$$


Table 1 Inclusion and exclusion criteria

Inclusion criteria
Population
Universal population of parents of infants $0-12$ months old in
western OECD countries

Exclusion criteria

\section{Population}

western OECD countries

\section{Intervention}

Structured psychosocial parenting intervention consisting of at least three sessions and initiated either antenatal or during the child's first year of life with at least half of the sessions delivered postnatally

Control group

No restrictions were imposed. All services or comparison interventions provided to the control group were allowed Outcome

Child development and parent-child relationship outcomes

\section{Design}

Randomised controlled trials (RCT) or quasi-RCTs

\section{Publication type}

Studies presented in peer-reviewed journals, dissertations, books or scientific reports
Studies offered to a selected or indicated group of parents; including studies only offered to young mothers (<20 years), divorced parents, parents with mental health problems such as abuse and depression and children born preterm, at low birth weight or with congenital diseases

Interventions not focused specifically on parenting (eg, baby massage, reading sessions with child, or breastfeeding interventions), and unstructured interventions (eg, home visits if they are not offered in a structured format)

Studies reporting only physical development such as height and weight

Papers with insufficient quantitative outcome data to generate standardised mean differences (Cohen's d), risk ratios (RRs) and $\mathrm{Cls}$

Other study designs (such as case-control, cohort, cross-sectional and systematic reviews)

Abstracts or conference papers. Studies published in languages others than English, German or the Scandinavian languages (Danish, Swedish and Norwegian) where $\mathrm{N}=\mathrm{n}_{1}+\mathrm{n}_{2}$ is the total sample size, $\mathrm{X}_{1}$ and $\mathrm{X}_{2}$ are the mean in each group and $s_{p}$ is the pooled SD defined as: $\mathrm{s}_{\mathrm{p}}=\left(\left[\left(\mathrm{n}_{1}-1\right)\left(\mathrm{s}_{1}\right)^{2}+\left(\mathrm{n}_{2}-1\right)\left(\mathrm{s}_{2}\right)^{2}\right) /\left(\mathrm{n}_{1}+\mathrm{n}_{2}-2\right)\right]^{1 / 2} \quad$ (Lipsey and Wilson, 2001). We used the raw SDs, that is, $s_{1}$ and $s_{2}$ signify the unadjusted SD of the intervention and control group postintervention. For dichotomous outcomes, risk ratios (RRs) with 95\% CIs were used as the effect size metric. Data used to calculate Cohen's d included postintervention and follow-up means, SDs and sample size. Furthermore, t-values, F-tests, $\chi^{2}$, $\mathrm{p}$ values, $\beta$-coefficients and adjusted mean differences were used. Data used to calculate RRs were number of events and sample sizes or ORs. When using ORs, the RR was approximated based on OR and risk 0 using the method presented in Zhang and Yu. ${ }^{35}$ When insufficient numeric outcome information was included in the paper to calculate effect sizes, we contacted the corresponding author for more information. All studies but one were randomised at the individual level. When calculating effect sizes and CIs for the outcomes of the cluster-randomised study, we used methods described in Hedges ${ }^{36}$ to correct for the tendency towards overly narrow CIs. When available, we used data from adjusted analyses to calculate effect sizes. Effect sizes were calculated as shown in equation (1). While using the adjusted mean difference, we used the unadjusted SDs in order to be able to compare effect sizes calculated from unadjusted and adjusted means, respectively. We used the Practical Meta-Analysis Effect Size Calculator developed by
David B. Wilson, George Mason University, and provided by the Campbell Collaboration to calculate effect sizes.

\section{RESULTS}

The literature search yielded 17984 articles after removal of duplicates. A flow diagram of study inclusion is provided in figure 1. Seven studies (14 papers) met the inclusion criteria. A total of 2870 (1449 intervention, 1421 control) participants were included in the seven studies. Besides one cluster randomised study, ${ }^{37} 38$ all studies were randomised at the individual level. The seven trials examined the effects of different parenting interventions. Four studies were American, ${ }^{39-45}$ two were Australian $^{37} 3846$ and one study was Finnish. ${ }^{47-50}$ One paper was excluded due to insufficient numeric outcome to calculate effect sizes and CIs. ${ }^{51}$

\section{Participant characteristics}

Participant characteristics are presented in table 2. Three studies recruited only primiparous parents, whereas four recruited primiparous and multiparous parents. Two studies began in pregnancy, the remaining five started when infants where between 0 and 12 months old.

\section{Interventions and controls}

Four of the interventions were group-based, one was individual home visits and two interventions included 
Figure 1 Flow diagram for the study selection process.

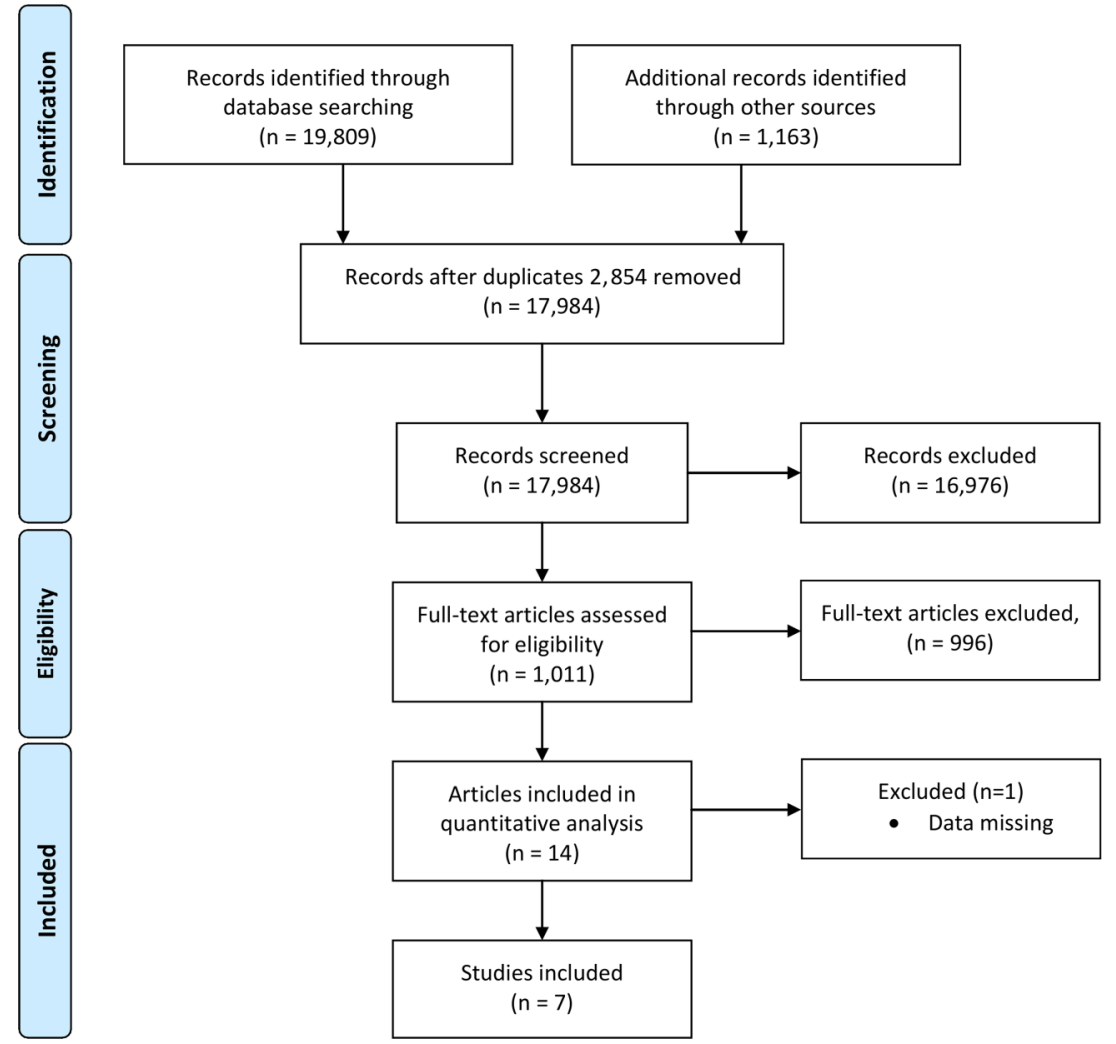

Table 2 Participant characteristics

\begin{tabular}{|c|c|c|c|c|c|c|}
\hline Study & Country & $\begin{array}{l}\text { Parent mean age } \\
\text { at start }\end{array}$ & Child age at start & Primiparous \% & Intervention (n) & Control (n) \\
\hline $\begin{array}{l}\text { Feinberg and } \mathrm{Kan}^{39} \\
\text { Feinberg et } a l^{40} 41 \\
\text { Solmeyer et } a l^{42}\end{array}$ & USA & $\begin{array}{l}\text { Mother: } 28.33 ; \\
\text { Father: } 29.76\end{array}$ & $\begin{array}{l}22.9 \text { weeks } \\
\text { gestation }\end{array}$ & 100 & 79 & 73 \\
\hline $\begin{array}{l}\text { Hiscock et } a^{\beta 7} \\
\text { Bayer et a }{ }^{\beta 8}\end{array}$ & Australia & Mother: 33.1 & Child age 8 months & 54 & 329 & 404 \\
\hline Doherty et $a{ }^{43}$ & USA & $\begin{array}{l}\text { Mother: } 30 \\
\text { Father: } 31\end{array}$ & Second trimester & 100 & 95 & 70 \\
\hline Vlismas et $a l^{46}$ & Australia & Mother: 32.62 & $\begin{array}{l}\text { Child mean age } \\
3.3 \text { months }\end{array}$ & 100 & 24 & 24 \\
\hline $\begin{array}{l}\text { Aronen }{ }^{47} \text { Aronen and } \\
\text { Kurkela }{ }^{48}{ }^{49} \text { Aronen } \\
\text { and Arajärvi }{ }^{50}\end{array}$ & Finland & Not reported & Child age 6 months & Not reported & 80 & 80 \\
\hline Dickie and Gerber ${ }^{44}$ & USA & Not reported & $\begin{array}{l}\text { Child mean age } \\
8.05 \text { months }\end{array}$ & 82 & 10 & 9 \\
\hline Minkovitz et a ${ }^{45}$ & USA & $\begin{array}{l}\text { Mother: age <20:14\%, } \\
20-29: 51 \%, \geq 30: 36 \%\end{array}$ & $\begin{array}{l}\text { Child age } \\
0-4 \text { weeks }\end{array}$ & 46 & 832 & 761 \\
\hline
\end{tabular}

individual home visits and group sessions. The majority of interventions were relatively short (3-8 sessions), but two were comparatively long (18-50 sessions) and lasted until the children were 3-5 years old. The control groups did not receive any intervention or were offered 'services as usual', minor interventions or waitlist. See table 3 for details of the interventions.

\section{Outcomes}

Most studies reported immediate postintervention outcomes, but half of the studies also reported short term (up to 6 months postintervention) and long-term (more than 6 months postintervention) follow-up outcome data. Four studies reported measures of child social-emotional development and three studies reported measures of parent-child relationship. Owing to heterogeneity in the outcome measures and the timing of follow-up assessments, we could not conduct any meta-analyses.

Individual studies

Feinberg and colleagues ${ }^{39-42}$ examined the effect of Family Foundations among 152 couples expecting their 


\begin{tabular}{|c|c|c|c|c|c|c|c|c|}
\hline Study & $\begin{array}{l}\text { No. of } \\
\text { sessions }\end{array}$ & Intervention & Delivery mode & Format & Intensity and duration & $\begin{array}{l}\text { Control } \\
\text { intervention }\end{array}$ & $\begin{array}{l}\text { Outcome } \\
\text { measures }\end{array}$ & $\begin{array}{l}\text { Child age at } \\
\text { assessment }\end{array}$ \\
\hline $\begin{array}{l}\text { Feinberg and } \\
\text { Kan }{ }^{39} \text { Feinberg } \\
\text { et }\left.a\right|^{40} 41 \\
\text { Solmeyer et } a l^{42}\end{array}$ & 8 & $\begin{array}{l}\text { Family Foundations } \\
\text { (FF). Aimed at } \\
\text { mothers and fathers }\end{array}$ & $\begin{array}{l}\text { Two group leaders } \\
\text { with } 3 \text { days training } \\
\text { offered at childbirth } \\
\text { education } \\
\text { departments at local } \\
\text { hospitals }\end{array}$ & Group & $\begin{array}{l}\text { Four sessions in } \\
\text { pregnancy, four sessions } \\
\text { after child is born until } \\
\text { about } 6.5 \text { months old }\end{array}$ & $\begin{array}{l}\text { The control group } \\
\text { received a brief } \\
\text { brochure in the } \\
\text { mail about } \\
\text { selecting quality } \\
\text { childcare }\end{array}$ & $\begin{array}{l}\text { Child } \\
\text { development } \\
\text { Parent-child } \\
\text { relationship }\end{array}$ & $\begin{array}{l}6.5 \text { and } \\
13.7 \text { months }\end{array}$ \\
\hline $\begin{array}{l}\text { Hiscock et } a \beta^{\beta 7} \\
\text { Bayer et } a l^{\beta 8}\end{array}$ & 3 & $\begin{array}{l}\text { Toddlers without } \\
\text { tears. Aimed at } \\
\text { mothers and fathers }\end{array}$ & $\begin{array}{l}\text { Nurse and parenting } \\
\text { expert/child } \\
\text { psychologist. } \\
\text { Offered at the local } \\
\text { Maternal and Child } \\
\text { Health centre/MCH) }\end{array}$ & Group & $\begin{array}{l}\text { Three sessions when infant } \\
\text { is } 8 \text { months }-15 \text { months old }\end{array}$ & $\begin{array}{l}\text { Treatment as } \\
\text { usual }\end{array}$ & $\begin{array}{l}\text { Child } \\
\text { development }\end{array}$ & $\begin{array}{l}8,24 \text { and } \\
36 \text { months }\end{array}$ \\
\hline Doherty et $a f^{43}$ & 8 & $\begin{array}{l}\text { Parenting Together. } \\
\text { Aimed at mothers } \\
\text { and fathers }\end{array}$ & $\begin{array}{l}\text { Licensed parent } \\
\text { educator. Group } \\
\text { sessions in clinic }\end{array}$ & $\begin{array}{l}\text { Home visit } \\
\text { and group }\end{array}$ & $\begin{array}{l}\text { One home visit and three } \\
\text { group sessions in } \\
\text { pregnancy, four group } \\
\text { sessions when the child is } \\
2-5 \text { months old }\end{array}$ & Not described & $\begin{array}{l}\text { Parent-child } \\
\text { relationship }\end{array}$ & 6 and 12 months \\
\hline Vlismas et $a f^{46}$ & 5 & $\begin{array}{l}\text { Face-to-face (F2F). } \\
\text { Aimed at mother } \\
\text { and child }\end{array}$ & $\begin{array}{l}\text { Psychologist led (the } \\
\mathrm{Pl} \text { ). Location not } \\
\text { reported }\end{array}$ & Group & $\begin{array}{l}\text { One weekly session for } \\
5 \text { weeks until the child is } \\
3-7 \text { months old }\end{array}$ & No treatment & $\begin{array}{l}\text { Parent-child } \\
\text { relationship }\end{array}$ & 3-7 months \\
\hline $\begin{array}{l}\text { Aronen }^{47} \\
\text { Aronen and } \\
\text { Kurkela }^{48} 49 \\
\text { Aronen and } \\
\text { Arajärvi }^{50}\end{array}$ & $\begin{array}{l}10 \text { times a } \\
\text { year for } \\
5 \text { years }\end{array}$ & $\begin{array}{l}\text { Psychodynamic } \\
\text { counselling. Aimed } \\
\text { at mothers and } \\
\text { fathers }\end{array}$ & Psychiatric nurse & Home visits & $\begin{array}{l}\text { Ten sessions a year from } \\
\text { birth until the child is } \\
5 \text { years old }\end{array}$ & $\begin{array}{l}3-6 \text { home visits } \\
\text { from birth until the } \\
\text { child is } 6 \text { months } \\
\text { old }\end{array}$ & $\begin{array}{l}\text { Child } \\
\text { development }\end{array}$ & $\begin{array}{l}10-11,14-15 \\
\text { and } 20-21 \text { years }\end{array}$ \\
\hline $\begin{array}{l}\text { Dickie and } \\
\text { Gerber }^{44}\end{array}$ & $\begin{array}{l}16 \text { hours } \\
\text { over } \\
8 \text { weeks }\end{array}$ & $\begin{array}{l}\text { Parent training. } \\
\text { Aimed at mothers, } \\
\text { fathers and infants }\end{array}$ & Not reported & Group & $\begin{array}{l}16 \text { hours over } 8 \text { weeks } \\
\text { when child is } 4-12 \text { months }\end{array}$ & $\begin{array}{l}\text { No treatment- } \\
\text { waiting list }\end{array}$ & $\begin{array}{l}\text { Parent-child } \\
\text { relationship }\end{array}$ & 6-14 months \\
\hline Minkovitz et a/5 & $\begin{array}{l}\text { Minimum } \\
6 \text { visits } \\
\text { during } \\
3 \text { years }\end{array}$ & $\begin{array}{l}\text { Healthy Steps for } \\
\text { Young Children. } \\
\text { Aimed at mothers } \\
\text { and fathers }\end{array}$ & $\begin{array}{l}\text { Trained Healthy } \\
\text { steps specialists. } \\
\text { Offered in homes } \\
\text { and at clinics }\end{array}$ & $\begin{array}{l}\text { Home visits, } \\
\text { individual } \\
\text { sessions } \\
\text { and groups }\end{array}$ & $\begin{array}{l}\text { Well-child visits, minimum } 6 \\
\text { home visits, telephone } \\
\text { hotline, developmental } \\
\text { assessments, written } \\
\text { materials, parent groups } \\
\text { and link to community } \\
\text { resources from birth to } \\
\text { age } 3\end{array}$ & $\begin{array}{l}\text { Treatment as } \\
\text { usual }\end{array}$ & $\begin{array}{l}\text { Child } \\
\text { development }\end{array}$ & $61-66$ months \\
\hline
\end{tabular}


first child and living in rural areas, towns and small cities in the USA. Families were recruited through childbirth education programmes at two local hospitals. The intervention was aimed at enhancing coparenting quality and consisted of eight sessions: four during the second and third trimesters and four in the first 6.5 months postpartum. The control group received a brief brochure in the mail about selecting quality childcare.

Hiscock and colleagues ${ }^{37} 38$ examined the effect of Toddlers without Tears in a cluster RCT, including 733 mothers recruited through maternal and child health nurses in Victoria, Australia. The intervention was aimed at reducing behavioural problems and consisted of three sessions from when the child was $8-15$ months old. The control group received services as usual and may have included general information for parents.

Aronen and colleagues ${ }^{47-50}$ examined the effect of psychodynamic counselling among 160 families in Helsinki, Finland, in 1975-1976. The families were randomly selected from the total birth cohort. All families received 3-6 home visits in the first 6 months of the child's life. When the infants were 6 months old, they were divided into high-risk or low-risk groups according to data records and assessment results and then randomised within the groups to receive either the intervention or to serve as a control family. The intervention was aimed at preventing mental disturbances by improving family interactions and childrearing practices and consisted of up to 10 home visits per year over 5 years. The control group did not receive any intervention.

Minkovitz et at $t^{45}$ examined Healthy Steps for Young Children in 1593 families with newborns at six different sites (hospital-based clinics and paediatric practices) across the USA from 1996 to1998. The full sample included 5565 families, but only the randomised subsample was included in this review. The intervention was aimed at enhancing the relationship between parents and their children and improving delivery of developmental and behavioural support services. The intervention consisted of well-child visits, a minimum of six home visits, a telephone hotline to discuss the baby's development, developmental assessments, written materials on infant development and health issues, parent support groups and referral to community resources from the birth of the child to age 3 years. The control group received the usual paediatric services.

Doherty et $a t^{43}$ examined Parenting Together among 165 families expecting their first child. Families were recruited through local obstetric clinics in the USA. The intervention was aimed at enhancing the quality of father-child interaction and consisted of eight sessions; the first session was a home visit during pregnancy, the next three sessions were group meetings during the second and third trimester and the last four sessions occurred 2-5 months postnatally. There was no description of the control group.

Vlismas $e t a l^{46}$ examined Face to Face (F2F) among 48 primiparous mothers. Families were recruited from three Maternal and Child Health Clinics in Brisbane, Australia. The overall aim of the study was to examine the effects of Music and Movement (M\&M) in a two-by-two factorial model, comparing M\&M with M\&M combined with F2F, F2F alone and a no intervention control condition. Since the M2M intervention does not meet the definition of a parenting intervention, we only used the results of the F2F group. The F2F intervention consisted of five group sessions when the infants were 24 months old; the control group did not receive an intervention. The F2F group sessions aimed to give parents instructions for play activities and to provide an opportunity to discuss parenting issues.

Dickie and Gerber ${ }^{44}$ examined parent training in 19 families in the USA. Families were recruited through a newspaper report. The intervention was aimed at increasing parental competence to assess, predict and respond to their infant and consisted of 16 hours of training over 8 weeks when the children were 412 months old. The families randomised to the control condition were put on a waiting list to receive the intervention following study assessments. It was only feasible to use a single outcome from this study because we lacked data to calculate standardised mean differences or could not calculate appropriate CIs for the other reported outcomes. Only statistically significant outcomes were reported in the study.

\section{Risk of bias}

Risk of bias assessment is shown in the online supplementary table S1. Assessments on the specific risk of bias domains were divided into child development and parent-child relationship outcomes, respectively. Overall, risk of bias was reasonable for all studies and revealed no major differences. Risk of bias was assessed as low to medium in those domains where a clear judgement could be made. However, many of the studies delivered insufficient information in relation to at least two risks of bias domains, thus hindering a clear judgement for all risk of bias domains.

\section{Child development}

Table 4 shows the individual results of the four studies reporting child development outcomes. Results from subscales are shown in the online supplementary table S2.

\section{Postintervention outcomes}

Two studies reported child development outcomes at postintervention. Feinberg and Kan found statistically significant positive effects on duration of orienting [0.34 $(0.02$ to 0.66$)]$, and infant soothability for fathers [0.33 $(0.01$ to 0.65$)]$, but not for mothers. There was no significant effect on child sleep habits. ${ }^{39}$ Hiscock et $a l^{37}$ found no significant effects on either of the two CBCL broadband subscales externalising or internalising behaviour. 
Table 4 Child development outcomes as reported across studies included in the systematic review

\begin{tabular}{|c|c|c|c|c|c|c|c|c|c|c|c|}
\hline \multirow[b]{2}{*}{ Study } & \multirow[b]{2}{*}{ Measure } & \multirow[b]{2}{*}{ Outcome } & \multirow[b]{2}{*}{ Assessment } & \multirow[b]{2}{*}{ Child age } & \multirow[b]{2}{*}{ Time } & \multicolumn{2}{|c|}{ Intervention } & \multicolumn{2}{|c|}{ Control } & \multirow[b]{2}{*}{ Cohen's d } & \multirow[b]{2}{*}{ Other statistics } \\
\hline & & & & & & $\mathrm{n}$ & Mean(SD) & $\mathrm{n}$ & Mean(SD) & & \\
\hline \multirow{3}{*}{$\begin{array}{l}\text { Feinberg } \\
\text { and } \mathrm{Kan}^{39}\end{array}$} & IBQ-R & Duration of orienting & $\mathrm{Q}$ & 6.5 months & $\mathrm{PI}$ & 79 & & 73 & & 0.34 (0.02 to 0.66$)$ & $F=4.33$ \\
\hline & IBQ-R & Infant soothability & $Q$ & 6.5 months & $\mathrm{PI}$ & 79 & & 73 & & $\begin{array}{l}\text { Mother: }-0.03 \\
(-0.34 \text { to } 0.29) \\
\text { Father: } \mathbf{0 . 3 3} \\
(\mathbf{0 . 0 1} \text { to } \mathbf{0 . 6 5 )}\end{array}$ & $\begin{array}{l}\text { Mother: } \beta=-0.021 \\
\text { SD of DV: } 0.84^{*} \\
\text { Father: } \beta=0.312 \\
\text { SD of DV: } 0.96^{*}\end{array}$ \\
\hline & $\begin{array}{l}\text { Child sleep } \\
\text { habits }\end{array}$ & Child sleep habits & $\mathrm{Q}$ & 6.5 months & $\mathrm{PI}$ & 79 & & 73 & & $0.27(-0.05$ to 0.58$)$ & $\beta=2.67$ \\
\hline \multirow[t]{2}{*}{$\begin{array}{l}\text { Feinberg } \\
\text { et } a f^{40}\end{array}$} & Homemade & $\begin{array}{l}\text { Child behaviour- } \\
\text { self-soothing }\end{array}$ & $\mathrm{v}$ & 13.7 months & SF & 73 & & 68 & & $\begin{array}{l}\text { Mother: } 0.42 \\
(0.09 \text { to } 0.76)\end{array}$ & $\begin{array}{l}\beta=0.30 \\
S D=0.73\end{array}$ \\
\hline & Homemade & $\begin{array}{l}\text { Child behaviour- } \\
\text { sustained attention }\end{array}$ & V & 13.7 months & SF & 73 & & 68 & & $\begin{array}{l}\text { Mother: } 0.06 \\
(-0.27 \text { to } 0.39)\end{array}$ & $\begin{array}{l}\beta=0.05 \\
S D=0.78\end{array}$ \\
\hline \multirow{3}{*}{$\begin{array}{l}\text { Feinberg } \\
\text { et }\left.a\right|^{41}\end{array}$} & CBCL & Total & $Q$ & 36 months & LF & 70 & $45.23(8.67)$ & 65 & $46.17(8.54)$ & $0.11(-0.23$ to 0.45$)$ & \\
\hline & $\begin{array}{l}\text { Head Start } \\
\text { Competence } \\
\text { Scale }\end{array}$ & Social competence & $Q$ & 36 months & LF & 69 & & 65 & & $0.43(0.09$ to 0.77$)$ & $\begin{array}{l}\beta=0.20 \\
S D \text { of } D V=0.48^{*}\end{array}$ \\
\hline & $\begin{array}{l}\text { Head Start } \\
\text { Competence } \\
\text { Scale }\end{array}$ & $\begin{array}{l}\text { Emotional } \\
\text { competence }\end{array}$ & $Q$ & 36 months & LF & 69 & & 65 & & $0.25(-0.09$ to 0.59$)$ & $\begin{array}{l}\beta=0.13 \\
S D \text { of } D V=0.53^{*}\end{array}$ \\
\hline $\begin{array}{l}\text { Solmeyer } \\
\text { et } a f^{42}\end{array}$ & Homemade & $\begin{array}{l}\text { Child adjustment } \\
\text { problems }\end{array}$ & v & 36 months & LF & 65 & $0.005(0.82)$ & 63 & $-0.01(0.65)$ & $-0.02(-0.37$ to 0.33$)$ & \\
\hline \multirow[t]{4}{*}{$\begin{array}{l}\text { Hiscock } \\
\text { et } a^{37}\end{array}$} & CBCL & Externalising & $Q$ & 18 months & $\mathrm{PI}$ & 295 & & 373 & & $-0.02(-0.20$ to 0.15$)$ & $\begin{array}{l}\text { Adjusted mean dif: } \\
0.16, S D \text { of } D V: \\
6.84^{*} \dagger\end{array}$ \\
\hline & $\mathrm{CBCL}$ & Internalising & $Q$ & 18 months & $\mathrm{PI}$ & 295 & & 373 & & $-0.12(-0.27$ to 0.04$)$ & $\begin{array}{l}\text { Adjusted mean dif: } \\
0.49, \text { SD of DV: } \\
4.26^{\star} \dagger\end{array}$ \\
\hline & CBCL & Externalising & $Q$ & 24 months & SF & 292 & & 362 & & $0.11(-0.07$ to 0.29$)$ & $\begin{array}{l}\text { Adjusted mean dif: } \\
-0.79, \text { SD of DV: } \\
7.31^{*} \dagger\end{array}$ \\
\hline & $\mathrm{CBCL}$ & Internalising & $Q$ & 24 months & SF & 292 & & 362 & & $-0.03(-0.19$ to 0.12$)$ & $\begin{array}{l}\text { Adjusted mean dif: } \\
0.19, \text { SD of DV: } \\
6.04^{*} \dagger\end{array}$ \\
\hline \multirow[t]{2}{*}{$\begin{array}{l}\text { Bayer } \\
\text { et } a^{\beta 8}\end{array}$} & CBCL & Externalising & $Q$ & 36 months & LF & 259 & & 330 & & $0.11(-0.08$ to 0.30$)$ & $\begin{array}{l}\text { Adjusted mean dif: } \\
-0.8 \\
\text { SD of DV: } 7.36^{\star} \dagger\end{array}$ \\
\hline & $\mathrm{CBCL}$ & Internalising & $\mathrm{Q}$ & 36 months & LF & 259 & & 330 & & $0.11(-0.05$ to 0.28$)$ & $\begin{array}{l}\text { Adjusted mean dif: } \\
-0.6 \\
\text { SD of DV: } 5.44^{*} \dagger\end{array}$ \\
\hline
\end{tabular}




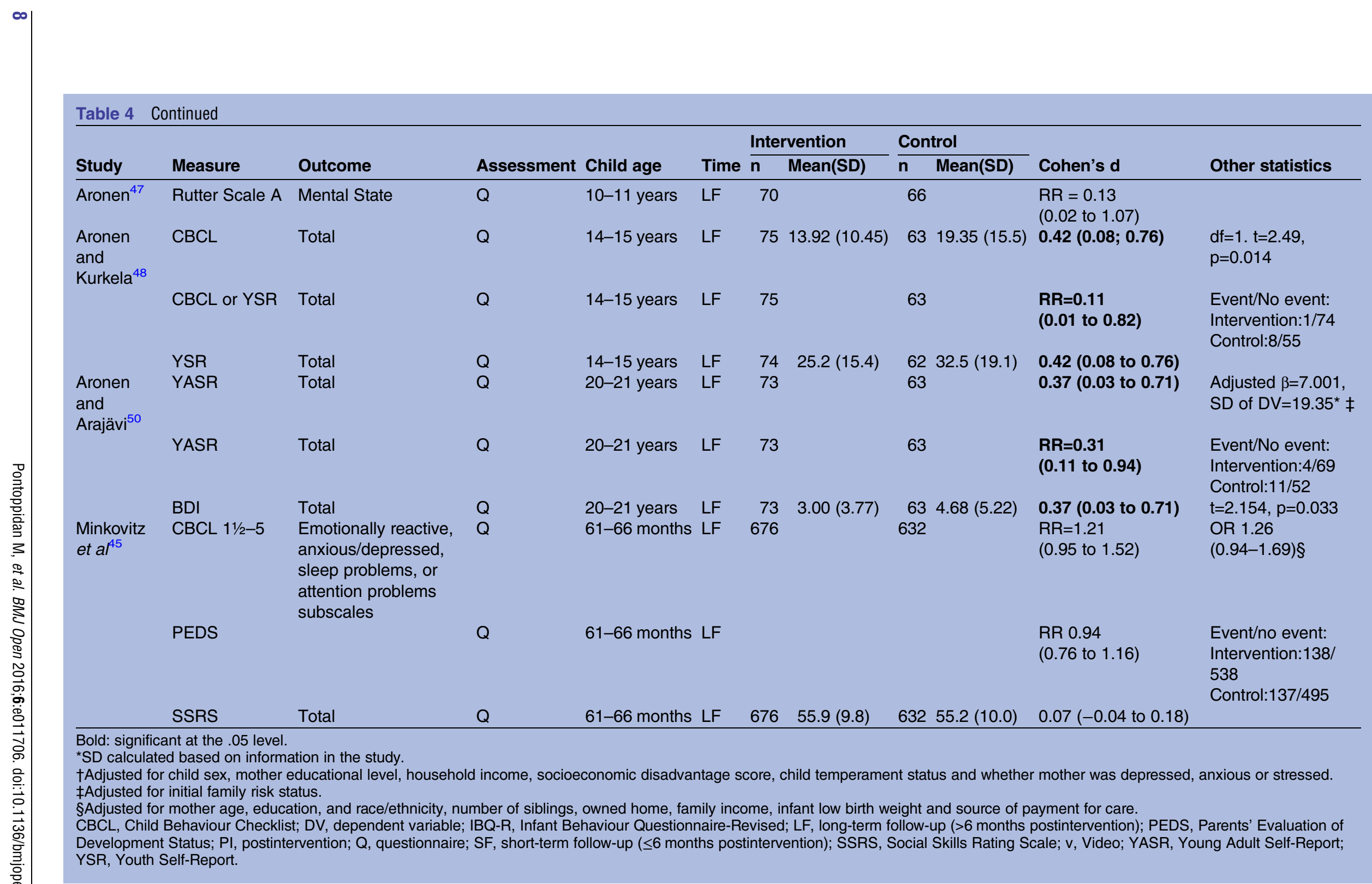


Table 5 Parent-child relationship outcomes as reported across studies included in the systematic review

\begin{tabular}{|c|c|c|c|c|c|c|c|c|c|c|c|}
\hline \multirow[b]{2}{*}{ Study } & \multirow[b]{2}{*}{ Measure } & \multirow[b]{2}{*}{ Outcome } & \multirow[b]{2}{*}{ Assessment } & \multirow[b]{2}{*}{ Child age } & \multirow[b]{2}{*}{ Time } & \multicolumn{2}{|c|}{ Intervention } & \multicolumn{2}{|c|}{ Control } & \multirow[b]{2}{*}{ Cohen's d } & \multirow[b]{2}{*}{ Other statistics } \\
\hline & & & & & & $\mathrm{n}$ & Mean (SD) & $\mathrm{n}$ & Mean (SD) & & \\
\hline \multirow{4}{*}{$\begin{array}{l}\text { Feinberg } \\
\text { et } a^{f^{0}}\end{array}$} & Homemade & Parenting-positivity & $\mathrm{V}$ & 13.7 months & SF & 70 & & 68 & & Mother: 0.36 & Mother: $\beta=0.30$ \\
\hline & & & & & & & & & & $\begin{array}{l}\text { Father: } 0.37 \\
(0.03 \text { to } 0.70)\end{array}$ & $\begin{array}{l}\text { Father: } \beta=0.32 \\
\text { SD of } D V: 0.89^{*}\end{array}$ \\
\hline & Homemade & Parenting—negativity & v & 13.7 months & SF & 70 & & 68 & & $\begin{array}{l}\text { Mother: } 0.58 \\
(0.24 \text { to } 0.93)\end{array}$ & $\begin{array}{l}\text { Mother: } \beta=-0.19 \text {, } \\
\text { SD of DV: } 0.34^{*}\end{array}$ \\
\hline & & & & & & & & & & $\begin{array}{l}\text { Father: } 1.38 \\
\text { (1.00 to } 1.75)\end{array}$ & $\begin{array}{l}\text { Father: } \beta=-0.34 \text {, } \\
\text { SD of DV: } 0.31^{*}\end{array}$ \\
\hline \multirow[t]{14}{*}{$\begin{array}{l}\text { Doherty } \\
\text { et } a f^{33}\end{array}$} & $\begin{array}{l}\text { Parent Behaviour } \\
\text { Rating Scale }\end{array}$ & $\begin{array}{l}\text { Total father-child } \\
\text { interaction }\end{array}$ & v & 6 months & $\mathrm{PI}$ & 70 & $29.78(7.30)$ & $62-64$ & $27.55(6.22)$ & $0.33(-0.02$ to 0.67$)$ & \\
\hline & $\begin{array}{l}\text { Parent Behaviour } \\
\text { Rating Scale }\end{array}$ & $\begin{array}{l}\text { Warmth and } \\
\text { emotional support }\end{array}$ & V & 6 months & $\mathrm{PI}$ & 70 & $4.76(1.59)$ & $62-64$ & $4.28(1.43)$ & $0.32(-0.03$ to 0.66$)$ & \\
\hline & $\begin{array}{l}\text { Parent Behaviour } \\
\text { Rating Scale }\end{array}$ & Intrusiveness & v & 6 months & $\mathrm{PI}$ & 70 & $4.89(1.43)$ & $62-64$ & $4.31(1.71)$ & $0.37(0.03$ to 0.71$)$ & \\
\hline & $\begin{array}{l}\text { Parent Behaviour } \\
\text { Rating Scale }\end{array}$ & $\begin{array}{l}\text { Engagement with } \\
\text { child }\end{array}$ & $\mathrm{V}$ & 6 months & $\mathrm{PI}$ & 70 & $5.49(1.40)$ & $62-64$ & $5.37(1.29)$ & $0.09(-0.25$ to 0.43$)$ & \\
\hline & $\begin{array}{l}\text { Parent Behaviour } \\
\text { Rating Scale }\end{array}$ & Positive affect & v & 6 months & $\mathrm{PI}$ & 70 & 4.69 (1.62) & $62-64$ & $4.33(1.39)$ & $0.24(-0.10$ to 0.58$)$ & \\
\hline & $\begin{array}{l}\text { Parent Behaviour } \\
\text { Rating Scale }\end{array}$ & Negative affect & v & 6 months & $\mathrm{PI}$ & 70 & $6.32(1.60)$ & $62-64$ & $6.62(0.76)$ & $-0.24(-0.58$ to 0.11$)$ & \\
\hline & $\begin{array}{l}\text { Parent Behaviour } \\
\text { Rating Scale }\end{array}$ & Dyadic synchrony & $\mathrm{V}$ & 6 months & $\mathrm{PI}$ & 70 & $3.64(1.90)$ & $62-64$ & $2.86(1.40)$ & $0.46(0.12$ to 0.81$)$ & \\
\hline & $\begin{array}{l}\text { Parent Behaviour } \\
\text { Rating Scale }\end{array}$ & $\begin{array}{l}\text { Total father-child } \\
\text { interaction }\end{array}$ & $\mathrm{V}$ & 12 months & SF & 70 & $29.72(6.65)$ & $62-64$ & $28.63(6.29)$ & $0.17(-0.17$ to 0.51$)$ & \\
\hline & $\begin{array}{l}\text { Parent Behaviour } \\
\text { Rating Scale }\end{array}$ & $\begin{array}{l}\text { Warmth and } \\
\text { emotional support }\end{array}$ & v & 12 months & SF & 70 & $4.71(1.59)$ & $62-64$ & $4.41(1.46)$ & $0.20(-0.15$ to 0.54$)$ & \\
\hline & $\begin{array}{l}\text { Parent Behaviour } \\
\text { Rating Scale }\end{array}$ & Intrusiveness & $\mathrm{V}$ & 12 months & SF & 70 & $4.81(1.52)$ & $62-64$ & $4.72(1.45)$ & $0.06(-0.28$ to 0.40$)$ & \\
\hline & $\begin{array}{l}\text { Parent Behaviour } \\
\text { Rating Scale }\end{array}$ & $\begin{array}{l}\text { Engagement with } \\
\text { child }\end{array}$ & V & 12 months & SF & 70 & $5.41(1.39)$ & $62-64$ & $5.18(1.42)$ & $0.16(-0.18$ to 0.50$)$ & \\
\hline & $\begin{array}{l}\text { Parent Behaviour } \\
\text { Rating Scale }\end{array}$ & Positive affect & V & 12 months & SF & 70 & $4.85(1.57)$ & $62-64$ & $4.52(1.41)$ & $0.22(-0.12$ to 0.56$)$ & \\
\hline & $\begin{array}{l}\text { Parent Behaviour } \\
\text { Rating Scale }\end{array}$ & Negative affect & v & 12 months & SF & 70 & $6.28(1.70)$ & $62-64$ & $6.77(0.66)$ & $-0.37(-0.7$ to -0.03$)$ & \\
\hline & $\begin{array}{l}\text { Parent Behaviour } \\
\text { Rating Scale }\end{array}$ & Dyadic synchrony & $\mathrm{V}$ & 12 months & SF & 70 & $3.66(1.76)$ & $62-64$ & $3.08(1.33)$ & 0.37 (0.03 to 0.71$)$ & \\
\hline
\end{tabular}




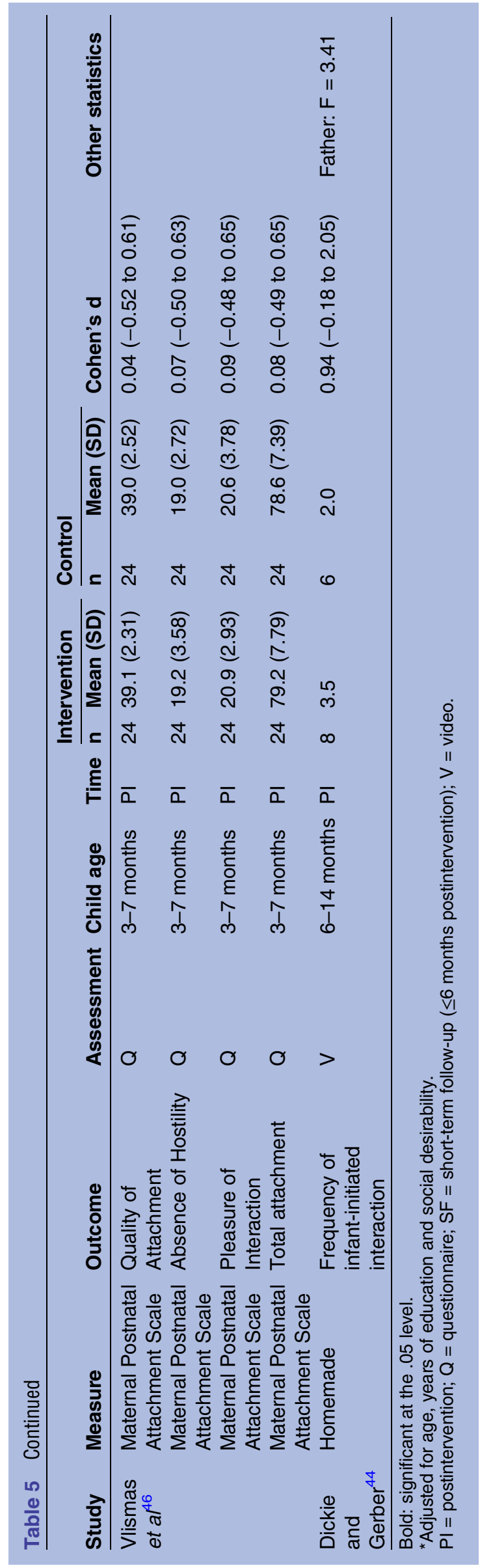

Short-term outcomes

Three studies reported child development outcomes at short-term follow-up (up to 6 months postintervention). Feinberg $e t a l^{40}$ found a significant positive effect on selfsoothing reported by mothers $[0.42(0.09$ to 0.76$)]$, but no significant effect on sustained attention. Hiscock et $a l^{37}$ found no significant effects on either of the two CBCL broadband subscales externalising or internalising behaviour. Minkovitz et a $\bar{l}^{1}$ reported relevant outcomes at short-term follow-up; however, we were not able to calculate standardised mean differences because of the lack of data and errors in the results table.

\section{Long-term outcomes}

Three studies reported child development outcomes at long-term follow-up (more than 6 months postintervention). Feinberg et $a l^{41}$ and Solmeyer et $a l^{42}$ found a significant effect on social competence $[0.43$ (0.09 to $0.77)]$, but no significant effects on emotional competence, child adjustment problems, total CBCL and CBCL subscales externalising, internalising, attention/ hyperactivity and aggression $\sim 30$ months postintervention. Bayer $e t a l^{88}$ found no significant effects on either of the two CBCL broadband subscales externalising or internalising behaviour around 21 months postintervention. Aronen ${ }^{47}$ found no significant effects on mental state at the 5-year follow-up. At the 10-year follow-up, Aronen and Kurkela found significant and positive effects of the intervention on CBCL total and broadband scales: Total [0.42 (0.08 to 0.76)], Internalising [0.39 (0.05 to 0.73)] and Externalising [0.36 (0.02 to $0.70)]$. Furthermore, significant positive effects ranging between 0.34 and 0.46 were found for the narrow-band subscales Somatic Symptoms, Anxious/Depressed, Attention Problems and Aggressive Behaviour. No significant effects on the Withdrawn, Social Problems, Thought Problems and Delinquent Behaviour subscales were found. Regarding the YSR total and broadband scores, there were significant positive effects on the Total Problems [0.42 (0.08 to 0.76)] and Internalising [0.52 $(0.17$ to 0.86$)]$ scales. Significant positive effects ranging from 0.36 to 0.60 were found for the Withdrawn, Anxious/Depressed and Thought Problems subscales. No significant effects on Externalising, Somatic Symptoms, Social Problems, Attention, Delinquent Behaviour and Aggressive Behaviour were found. Analyses of CBCL and YSR were combined into one dichotomous outcome (CBCL or YSR T-score of 64 or higher) that revealed a significantly decreased risk for problems in the intervention group compared with the control group $[R R=0.11$ (0.01 to 0.82) $].^{48}$ At the 15-year follow-up, Aronen and Arajärvi found significant positive effects on YASR Total [0.37 (0.03 to 0.71)] and Internalising 0.36 [0.02 to $0.70)$ ]. The relative risk of having a YASR T-score at 60 or higher was significantly lower for the intervention group compared with the control group $[\mathrm{RR}=0.31 \quad(0.11$ to 0.94)]. Significant positive effects were found for narrowband scores for the Anxious/Depressed Attention 
Problems subscales; effect sizes ranged between 0.34 and 0.38. In addition, a significant positive effect was found for depressive symptoms [BDI (0.37 (0.03 to 0.71)]. No significant effects were found on Externalising, Withdrawn, Somatic Symptoms, Intrusive, Thought Problems, Delinquent Behaviour and Aggressive Behaviour. ${ }^{50}$ Minkovitz et al found no statistically significant effects on SSRS Total score or the PEDS Total score 12-18 months postintervention. The relative risk of being in the clinical or borderline range of the CBCL subscale scores emotionally reactive, anxious/depressed, sleep problems or attention problems, or of parent's having significant concern regarding the child's development in PEDS were non-significant. ${ }^{45}$

\section{Parent-child relationship}

Table 5 shows the individual results of the four studies reporting parent-child relationship outcomes.

\section{Postintervention outcomes}

Three studies reported parent-child relationship outcomes at postintervention. Doherty et a $t^{43}$ found significant positive effects of the intervention on intrusiveness [0.37 (0.03 to 0.71$)]$ and dyadic synchrony [0.46 (0.12 to 0.81$)]$, but no significant effects on total score, warmth and emotional support, engagement with child and positive affect. Vlismas $e t a t^{46}$ found no significant effects on any of the reported outcomes (total attachment, quality of attachment, absence of hostility and pleasure of interaction). Dickie and Gerber ${ }^{44}$ found no significant effect on the frequency of infant-initiated interaction when using a $5 \%$ level of significance.

\section{Short-term outcomes}

Two studies reported parent-child relationship outcomes at short-term follow-up (up to 6 months postintervention). Feinberg et $a t^{40}$ found significantly increased positivity [mother: 0.36 (0.02 to 0.69$)$; father: 0.37 (0.03 to 0.70$)$ ] and reduced negativity [mother: 0.58 (0.24 to 0.93); father: 1.38 (1.00 to 1.75 )]. Doherty et al found a significant positive effect on dyadic synchrony $[0.37$ (0.03 to 0.71$)$ ], but no significant effects on total score, warmth and emotional support, engagement with child, positive affect and intrusiveness. They found a significant negative effect of the intervention on negative affect $[-0.37(-0.76$ to -0.03$)]$, meaning that at shortterm follow-up, the control group was doing better than the intervention group with regard to negative affect. ${ }^{43}$

\section{Long-term outcomes}

No studies reported long-term results of parent-child relationship outcomes.

\section{DISCUSSION}

We identified 14 papers representing 7 RCTs that examined the effects of universal parenting interventions for families with infants $0-12$ months old. We could not perform meta-analysis on any outcomes due to heterogeneity in the outcome measures and the timing of follow-up assessments. Examining the individual studies, no consistent results were found across the seven studies. Four studies reported child development outcomes (of which one study also reported parent-child relationship outcomes). Of these, two reported one or more significant positive effects on child development, ${ }^{3947}$ while the other two did not. ${ }^{51}{ }^{52}$ Four studies reported parentchild relationship outcomes. Two of these studies found one or more significant positive effect: ${ }^{39}{ }^{43}$ however, one of the studies also found a significant negative effect. ${ }^{43}$ Two studies found no significant effects of the parenting interventions. ${ }^{44}{ }^{46}$ Small to medium effect sizes were reported for the majority of the studies with statistically significant results (Cohen's d 0.33-0.60). Overall, more than half of the child development and parent-child relationship outcomes reported in the papers showed no significant effect of receiving the intervention.

The studies were varied in the interventions, methods, control conditions, outcome measures and timing of follow-up assessments. These varied approaches may have contributed to the overall finding that the evidence for use of universal interventions is currently unclear. These differences may have led to unclear conclusions for several reasons. There may be differences between interventions initiated in pregnancy compared with interventions initiated after a child is born. Two studies were initiated during pregnancy with four sessions offered prenatally and four session offered after the birth of the infant. ${ }^{39-43}$ These two studies found conflicting results at short-term follow-up: one study found a statistically significant result of Parent Negativity in favour of the intervention group, ${ }^{39}$ whereas the other found a statistically significant effect of Negative Affect in favour of the control condition. ${ }^{43}$ For Father Positivity, one study ${ }^{40}$ found a positive significant effect, while the other $^{43}$ did not. There were no consistent differences in effects between studies that included antenatal sessions and exclusively postnatal interventions.

There may be different effects according to duration and timing of the interventions. Three of the five relatively short interventions did not show any significant effects for either outcome evaluated. ${ }^{3744}$ The remaining two found significant positive effects on child development ${ }^{43}$ and significant (positive and negative) effects on parent-child relationship. ${ }^{39}$ The two longer interventions, which ran for 3 and 5 years, respectively, also showed conflicting results; one found no significant effects $^{51}$ and the other found significant positive results of the intervention on child development in two of the three follow-up assessments. ${ }^{49}$ Given the results, there was no clear indication whether the duration of the intervention affected the outcomes.

Differential effects may have resulted from the timing of the assessments. Three studies reported child development outcomes between 2 and $2^{1 / 2}$ years postintervention, ${ }^{38414245}$ and one study reported outcomes at 5, 10 
and 15 years postintervention. ${ }^{47} 4850$ Significant positive results of the interventions were found at postintervention, short-term follow-up and long-term follow-up; however, for the majority of outcomes, there was no effect at all time points. Three studies reported parent-child relationship outcomes at postintervention ${ }^{43} 44 \quad 46$ and two studies reported outcomes at short-term follow-up. ${ }^{40}$ Significant positive results were found at both time points; however, the majority of outcomes showed no effects. One statistically significant negative effect for those receiving an intervention was found at short-term follow-up. Results were also mixed for assessment timing and there were no consistent trends for the effects.

Methodological issues such as sample size and implementation of the intervention could also have influenced these results. Generally, larger studies have more power to detect significant effects compared with small studies. The 7 studies included in this review differed with regard to sample size; the smallest included 19 participants, the largest 1593. The 2 smallest studies included 19 and 48 participants ${ }^{44}$ and found no significant intervention effects on parent-child relationship (no child development outcomes were reported). The 3 medium-sized studies included 152-165 participants $^{39} 4347$ and they all found one or more significant outcome on child development and parent-child relationship; whereas the two large studies that included 733 and 1593 participants ${ }^{51} 52$ found no significant effects on child development (no parent-child relationship outcomes were reported). The sample size did not indicate a consistent trend in these studies.

Implementation quality may have at least partly explained the mixed findings in this review. Implementation quality has become a focus of intervention studies in recent years because of how it may impact treatment outcomes. Four studies 37394351 in the present review reported at least some information about implementation, such as how many sessions the parents attended and treatment quality of the intervention. More details about training, certification and supervision of interventionists would also provide valuable information about treatment quality. Without a more comprehensive overview of the implementation process, it is difficult to assess whether the findings could have been affected by implementation quality. Inclusion of basic implementation information, such as the level of practitioner fidelity to the intervention and the parent completion rate of the intervention, would have provided a clearer picture of how well the interventions were delivered across the different studies.

This review was developed employing broad search and scope and included parenting interventions with diverse approaches and lengths. The broad scope facilitated the identification of as many relevant parenting intervention studies as possible. We chose to include only RCTs in order to ensure high methodological quality and minimise the risk of potential confounding factors. While both of these inclusion criteria can be seen as strengths, the rather strict criteria of only including RCTs may also be a limitation as it may have made it more difficult to find comparable studies with respect to intervention approaches. There may be non-randomised studies evaluating the effects of parenting interventions that could be relevant to this area of research; however, results from such studies would be subject to their own set of qualifying factors. A further limitation of the study was the large variation in outcomes measures used and different timing of assessments across studies. Owing to this heterogeneity, we could not conduct any meta-analyses.

\section{CONCLUSION}

This review identified seven studies evaluating the effects of interventions for a universal population of parents with infants on child development and parent-child relationship outcomes. The results were mixed and inconclusive for the primary aim of this review. For more than half of the outcomes, there were no differences between the intervention and control families. Three studies found one or more significant positive effects of participating in the intervention for child development or improving parent-child relationship; however, one of these studies also found a significant negative effect on parent-child relationship for the intervention group, and four studies did not find any significant effects. This review indicates that there are mixed results of universal parenting interventions for families with infants $0-12$ months, and no clear conclusions can currently be drawn regarding effects of this type of intervention on child development and parent-child relationship.

Twitter Follow Maiken Pontoppidan at @maikenpontop

Acknowledgements The authors would like to acknowledge and thank information specialists Anne-Marie Klint Jørgensen and Bjørn Christian Viinholt Nielsen for running the database searches, Rikke Eline Wendt for being involved in the review process, the research assistants doing the screening and senior researcher Trine Filges and researcher Jens Dietrichson for statistical advice.

Contributors MP conceptualised and designed the study, co-led the review process, contributed to screening, data extraction and data synthesis, drafted the first manuscript, critically revised the manuscript and approved the final manuscript as submitted. SBR co-led the review process, contributed to study design, screening, data extraction and data synthesis, performed risk of bias judgement, drafted the first manuscript, critically revised the manuscript and approved the final manuscript as submitted. SKK and JP contributed to study design, data synthesis, critically revised the manuscript and approved the final manuscript as submitted.

Funding MP was supported by the Danish National Board of Social Services and grant number 7-12-0195 from the philanthropic foundation TrygFonden. SBR was supported by a grant from the Danish Ministry of Social Affairs and the Interior.

Competing interests MP is the principal investigator for an RCT of the Incredible Years Parents and Babies Program as a universal intervention for parents with infants. The study is not yet published and therefore not included in this review. SKK is currently the principal investigator for an RCT evaluating the effectiveness of the Incredible Years Baby Program that is offered as a universal intervention in Norwegian health stations. She will also serve as a coauthor on MP's evaluation. 
Provenance and peer review Not commissioned; externally peer reviewed.

Data sharing statement No additional data are available.

Open Access This is an Open Access article distributed in accordance with the Creative Commons Attribution Non Commercial (CC BY-NC 4.0) license, which permits others to distribute, remix, adapt, build upon this work noncommercially, and license their derivative works on different terms, provided the original work is properly cited and the use is non-commercial. See: http:// creativecommons.org/licenses/by-nc/4.0/

\section{REFERENCES}

1. ZeanahJr $\mathrm{CH}$, Zeanah $\mathrm{P}$. The scope of infant mental health. In Zeanah $\mathrm{CH}$ Jr, ed. Handbook of infant mental health. New York: The Guilford Press, 2009.

2. Center on the Developing Child at Harvard University. The foundations of lifelong health are built in early childhood. 2010.

3. Carter AS, Briggs-Gowan MJ, Davis NO. Assessment of young children's social-emotional development and psychopathology: recent advances and recommendations for practice. J Child Psychol Psychiatry 2004;45:109-34.

4. Skovgaard AM, Houmann T, Christiansen E, et al. The prevalence of mental health problems in children 1(1/2) years of age-the Copenhagen Child Cohort 2000. J Child Psychol Psychiatry 2007;48:62-70.

5. Briggs-Gowan MJ, Carter AS, Bosson-Heenan J, et al. Are infant-toddler social-emotional and behavioral problems transient? J Am Acad Child Adolesc Psychiatry 2006;45:849-58.

6. Wakschlag LS, Danis B. Characterizing early childhood disruptive behavior. In: Zeanah $\mathrm{CH}$, ed. Handbook of infant mental health. New York, NY, USA: Guilford Press, 2009:392.

7. National Scientific Council on the Developing Child. Establishing a Level Foundation for Life: Mental Health Begins in Early Childhood. Working Paper No. 6. 2012.

8. Bolten MI. Infant psychiatric disorders. Eur Child Adolesc Psychiatry 2013;22(Suppl 1):S69-74.

9. Skovgaard AM, Olsen EM, Christiansen E, et al. Predictors (0-10 months) of psychopathology at age $1 \frac{11}{2}$ years-a general population study in The Copenhagen Child Cohort CCC 2000. J Child Psychol Psychiatry 2008;49:553-62.

10. Piquero AR, Farrington DP, Welsh BC, et al. Effects of early family/ parent training programs on antisocial behavior and delinquency. Campbell Syst Rev 2008;11.

11. Conti G, Heckman JJ. Economics of child well-being. In: Ben-Arieh A, Casas F, Frønes I, et al., eds. Handbook of child well-being. Dordrecht: Springer Netherlands, 2014:363-401.

12. Heckman JJ. The case for investing in disadvantaged young children. In: Darling-Hammond L, Grunewald R, Heckman JJ, et al., eds. Big ideas for children: investing in our nation's future. Washington, DC: First Focus, 2008:49-58.

13. Dishion TJ, Shaw D, Connell A, et al. The family check-up with high-risk indigent families: preventing problem behavior by increasing parents' positive behavior support in early childhood. Child Dev 2008;79:1395-414.

14. Barlow J, Parsons J. Group-based parent-training programmes for improving emotional and behavioural adjustments in 0-3-year-old children. Cochrane Database Syst Rev 2003;(1):CD003680.

15. Coleman PK, Karraker KH. Self-efficacy and parenting quality: findings and future applications. Dev Rev 1998;18:47-85.

16. Cowan CP, Cowan PA. Interventions to ease the transition to parenthood. Why they are needed and what they can do. Fam Relat 1995;44:412-23.

17. Petch J, Halford WK. Psycho-education to enhance couples' transition to parenthood. Clin Psychol Rev 2008;28:1125-37.

18. Corby B. Child abuse: towards a knowledge base. Philadelphia: Open University Press, 2000.

19. Geffner R, Igelman RS, Zellner J. The effects of intimate partner violence on children. New York: Haworth Maltreatment \& Trauma Press, 2003.

20. Grøgaard J. Dype spor. Oslo, Norway: Barne og familiedepartementet, 2007.

21. Kazdin AE, Weisz JR. Introduction. Context, background, and goals. In: Evidence-based psychotherapies for children and adolescents. New York: Guilford Press, 2010:3-9.

22. Fonagy $P$. Prevention, the appropriate target of infant psychotherapy. Infant Ment Health J 1998;19:124-50.

23. Gordon RS. An operational classification of disease prevention. Public Health Rep 1983;98:107-9.
24. Knudsen El, Heckman JJ, Cameron JL, et al. on building America's future workforce. Proc Natl Acad Sci USA 2006;103:10155-62.

25. Darling-Hammond L, Grunewald R, Heckman JJ, et al. Big ideas for children: investing in our nation's future, 2008.

26. Heckman JJ, Masterov DV. The productivity argument for investing in young children. Appl Econ Perspect Policy 2007;29:446-93.

27. Doyle O, Harmon CP, Heckman JJ, et al. Investing in early human development: timing and economic efficiency. Econ Hum Biol 2009;7:1-6.

28. Olds DL, Sadler L, Kitzman H. Programs for parents of infants and toddlers: recent evidence from randomized trials. J Child Psychol Psychiatry 2007;48:355-91.

29. Barlow J, Smailagic N, Bennett C, et al. Individual and group based parenting programmes for improving psychosocial outcomes for teenage parents and their children. Cochrane Database Syst Rev 2011;(3):CD002964.

30. Haroon M. Commentary on 'Behavioural and cognitive-behavioural group-based parenting programmes for early-onset conduct problems in children aged 3 to 12 years'. Evid Based Child Health 2013;8:693-4.

31. Barlow J, Stewart-Brown S. Why a universal population-level approach to the prevention of child abuse is essential. Child Abus Rev 2003;12:279-81.

32. Sanders MR, Cann W, Markie-Dadds C. Why a universal population-level approach to the prevention of child abuse is essential. Child Abus Rev 2003;12:145-54.

33. Offord DR. Selection of levels of prevention. Addict Behav 2000;25:833-42.

34. Green S, Higgins JPT, Alderson $P$, et al. Cochrane handbook: Cochrane reviews: ch 8: assessing risk of bias in included studies. In: Cochrane handbook for: systematic reviews of interventions, 2011:3-10.

35. Zhang J, Yu KF. What's the relative risk? A method of correcting the odds ratio in cohort studies of common outcomes. JAMA 1998;280:1690-1.

36. Hedges L V. Effect sizes in cluster-randomized designs. J Educ Behav Stat 2007;32:341-70.

37. Hiscock H, Bayer JK, Price A, et al. Universal parenting programme to prevent early childhood behavioural problems: cluster randomised trial. BMJ 2008;336:318-21.

38. Bayer JK, Hiscock H, Ukoumunne OC, et al. Three-year-old outcomes of a brief universal parenting intervention to prevent behaviour problems: randomised controlled trial. Arch Dis Child 2010;95:187-92.

39. Feinberg ME, Kan ML. Establishing family foundations: intervention effects on coparenting, parent/infant well-being, and parent-child relations. J Fam Psychol 2008;22:253-63.

40. Feinberg ME, Kan ML, Goslin MC. Enhancing coparenting, parenting, and child self-regulation: effects of family foundations 1 year after birth. Prev Sci 2009;10:276-85.

41. Feinberg ME, Jones $\mathrm{DE}, \mathrm{Kan} \mathrm{ML}$, et al. Effects of family foundations on parents and children: 3.5 years after baseline. J Fam Psychol 2010;24:532-42.

42. Solmeyer AR, Feinberg ME, Coffman DL, et al. The effects of the family foundations prevention program on coparenting and child adjustment: a mediation analysis. Prev Sci 2014;15:213-23.

43. Doherty WJ, Erickson MF, LaRossa R. An intervention to increase father involvement and skills with infants during the transition to parenthood. J Fam Psychol 2006;20:438-47.

44. Dickie JR, Gerber SC. Training in social competence: the effect on mothers, fathers, and infants. Child Dev 1980;51:1248-51.

45. Minkovitz CS, Strobino D, Mistry KB, et al. Healthy Steps for Young Children: sustained results at 5.5 years. Pediatrics 2007;120:e658-68.

46. Vlismas W, Malloch S, Burnham D. The effects of music and movement on mother-infant interactions. Early Child Dev Care 2012;1-20.

47. Aronen ET. The effect of family counselling on the mental health of 10-11-year-old children in low- and high-risk families: a longitudinal approach. J Child Psychol Psychiatry 1993;34:155-65.

48. Aronen ET, Kurkela SA. Long-term effects of an early home-based intervention. J Am Acad Child Adolesc Psychiatry 1996;35:1665-72.

49. Aronen ET, Kurkela SA. The predictors of competence in an adolescent sample: a 15-year follow-up study. Nord J Psychiatry 2009;52:203-12.

50. Aronen ET, Arajärvi T. Effects of early intervention on psychiatric symptoms of young adults in low-risk and high-risk families. Am J Orthopsychiatry 2000;70:223-32.

51. Minkovitz CS, Hughart N, Strobino D, et al. A practice-based intervention to enhance quality of care in the first 3 years of life: the Healthy Steps for Young Children Program. JAMA 2003;290:3081-91.

52. Bayer J, Hiscock H, Scalzo K, et al. Systematic review of preventive interventions for children's mental health: what would work in Australian contexts? Aust N Z J Psychiatry 2009;43:695-710. 